\title{
Economic Analysis of the Role of Farmer Organizations in Enhancing Smallholder Potato Farmers' Income in Middle Guinea
}

\author{
Emmanuel Tolno ${ }^{1}$, Hajime Kobayashi ${ }^{2}$, Matsumura Ichizen ${ }^{2}$, Mohamed Esham $^{3} \&$ Boubacar Siddighi Balde ${ }^{1}$ \\ ${ }^{1}$ The United Graduate School of Agricultural Sciences, Tottori University, Tottori, Japan \\ ${ }^{2}$ Faculty of Agriculture, Tottori University, Tottori, Japan \\ ${ }^{3}$ Faculty of Agricultural Sciences, Sabaragamuwa University of Sri Lanka, Belihuloya, Sri Lanka \\ Correspondence: Emmanuel Tolno, The United Graduate School of Agricultural Sciences, Tottori University, \\ Tottori, Japan. Tel: 81-80-4261-4533. E-mail: tresoremma84@hotmail.com
}

Received: December 8, 2014 Accepted: January 5, 2015 Online Published: February 15, 2015

doi:10.5539/jas.v7n3p123 URL: http://dx.doi.org/10.5539/jas.v7n3p123

\begin{abstract}
Farmers' organizations are inclusive of the poor and are charged with the purpose of becoming a market outlet for smallholder farmers in Guinea. Improving farmers' income earning capability and agricultural productivity has been an important strategy of Guinea's agriculture development policy. However, despite their growing importance, empirical studies on how farmers' organizations have impacted their members' income are limited in Guinea. This paper investigates the determinants and effects on farm income of group membership, using the sample of 90 smallholder potato producers in Middle Guinea. A probit model was used as a selection equation to identify factors that influence group membership decision by smallholder potato farmers. The results revealed that the age of the potato farmers, land ownership, extension service, credit access and off-farm income are positively associated with group membership while gender and education level of the farmer negatively influenced their decision to join farmer groups. Results of the second stage outcome equation found positive farm income effects of group membership. Furthermore, results revealed that farm income is predominantly determined by labor used, the size of the cultivated potato area, share of potato sold and potato market price. Since farmers are resource-poor and that farmer organizations are constrained by various institutional, technical and investment constraints despite their potential, it is recommended that favorable polices should be geared toward smallholder agriculture in Guinea in order to ensure the success of farmer organizations. Our results show that farmer groups can be an important institution for the transformation of smallholder farming, increase productivity and incomes thereby reducing poverty. Agricultural policies in Guinea should therefore focus more on the intensification of agriculture and farmers' organizations and increase the market orientation of the smallholder farm sector.
\end{abstract}

Keywords: farmer organizations, potato production, Fouta Djallon Farmers' Federation, smallholder farmers, Middle Guinea

\section{Introduction}

Smallholder agriculture is argued to remain important for economic development and poverty reduction in developing countries, but its development is challenged by the need for institutional innovations to overcome market failures (World Bank, 2008; Hazell et al., 2010). There is a renewed interest from donors, governments and researchers in cooperative producer organizations as an institutional vehicle to improve smallholder agricultural performance, particularly through improved market participation (Bernard \& Spielman, 2009; Fisher \& Qaim, 2012a, 2012b). Smallholder producers participation in market-oriented production holds potential for diversifying their incomes and increase agriculture productivity hence promoting food security and poverty eradication. With the numerous farming problems in developing countries, low agricultural productivity has negative effects on the economic welfare of the rural populations. Farmers' organizations have been suggested as a key tool to improve the living conditions of the resource-poor farmers in developing countries. There is a positive effect on small-scale farmers' income from being member in a farmers' organization (Bachke, 2009). And membership to such organizations is considered to increase the level of agricultural production and yield economic benefit to farmers as well as promote their general welfare (Oyeyinka et al., 2009; Mwaura, 2014). 
In many developing countries, including Guinea, agriculture is often referred to as the backbone of the economy, contributing to about $25 \%$ of the Gross Domestic Product (Guinea, Country Strategy Paper 2012-2016). The sector emerges as a key tool in achieving economic growth and poverty reduction and its potential to meet the increasing demand for food, depends largely on the productivity and market access of small farms.

However, smallholder farmers in Guinea are predominantly resource-poor and live in a hybrid world; their participation in commercialized production is generally limited by various institutional, technical and investment constraints. With the increase lack of agricultural production resources, smallholder farmers try to find the means to simultaneously guarantee household food security and maximize income from agriculture. Thus, in pursuing strategies of survival and in seeking prosperity, small farmers gather resources from wherever available, whether through formal or informal systems. In the midst of these, farmers have resulted in a number of options to enhance their farm production and improve their well-being. One of these options includes pooling their resources and working together as members of farmers' organization (FO). The justification arises from their potential in realizing pro-poor economic growth and sustainably empowering small scale farmers. Fischer and Qaim (2012a, 2013); Olwande and Mathenge (2012) indicate that organization among smallholder farmers has proved to be one of the means for smallholder farmers to overcome market imperfections. Strong and vibrant farmers' organizations can provide opportunities to farmers to effectively play a role in the market economy and benefit from it (Millie et al., 2006).

Economic benefits mainly income, is the primary motivation for producers to join these farmers' groups; failing to get the desired benefit could threaten their participation in such entities. While aiming at increasing farmers income by providing services at lower costs and better prices for their produce, the expected role of farmer organizations could be challenged by various problems such as poor infrastructures, lack of investment, inadequate service provision, poor extension services, competition with local traders, etc. To our knowledge, not much research has been done on farmers' organizations in Guinea and empirical studies on their socioeconomic impacts are limited. Therefore, in light of the above mentioned and given the assumed role of farmers' organizations in Guinea, the present study seeks to contribute to the existing body of literature and research on farmer organizations in Guinea. The study attempts to assess the effects of farmer organizations on smallholder potato producers in Guinea. More specifically the objective is to identify the factors that influence the farmers' decision to participate in farmer groups. Furthermore, by comparing producer members of farmer organizations and non-members, we analyze the effects of group membership on farm income among smallholder potato producers.

\subsection{An Overview of Guinea Agricultural Development}

The principal activity and primary source of income is Agriculture for the vast majority of the population in Guinea. Despite the wealth of resources, Guinea remains an underdeveloped country and the majority of its population continues to live in poverty. More than $52 \%$ of the country's poor population lives in rural areas and most cultivation is carried by smallholding farmers who make up nearly $80 \%$ of the population. In the years leading up to independence, several programs were launched to improve the agricultural sector (Table 1). However, the compulsory character of the system, the international management problem and the insufficient extension support were among the numerous problems that handicapped the survival of the colonial agricultural system after the country got its independence (Bah, 1998). Committed to meeting all the development challenges, the government set as its major objective, the achievement of an annual agricultural Gross Domestic Product (GDP) growth rate of $10 \%$ (in 2010) and has made the agricultural sector the priority of its economic and social development policy. As in much of Sub-Saharan countries, the Guinean government engaged in the general and imperative structural adjustment programs, prolonged and amplified in the years 1990 by the increasing liberalization of market exchanges. Farmer based organizations have attracted interest as vehicles for providing an array of collective services including common property management, technology development and testing and management of rural infrastructure, and marketing of key production inputs or farm outputs (Tinsley, 2004). During the First and Second Republic, the economic and agricultural reforms aimed at boosting rural and economic development. However, other areas where the public sector has traditionally supported the agricultural sector in particular were neglected; agricultural research, training, and extension activities were ignored, rural infrastructure deteriorated, and the state's responsibilities as manager and protector of publicly owned natural resources were not met. Despite some progress made in improving the conditions for the rural population, productivity is still low because farmers have little access to information, new technologies, basic infrastructure and rural financial services. In 2008, the Government introduced a series of reforms and resolutions to address the worsening poverty and social deterioration in the country. The Poverty Reduction Strategy Paper (PRSP) and the National Policy on Agricultural Development - Vision 2015, were adopted and focused on development of 
the crop and livestock subsectors and the national food security strategy. The Government intends to ensure food security in the country and to become a food exporter. The plan seeks to attract private sector investments and is designed to contribute to a significant reduction in poverty through rural development, thereby helping to reverse socio-economic decline.

Table 1. Summary of Guinea agricultural policies

\begin{tabular}{|c|c|c|c|c|}
\hline Period & Agricultural Policy & Objective & Characteristics & Results \\
\hline 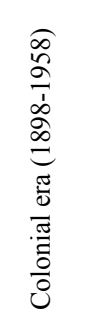 & $\begin{array}{l}\text { Agricultural } \\
\text { Development Policy }\end{array}$ & Improve rice production & $\begin{array}{l}\text { Farming organization and management pattern } \\
\text { were intricately connected to the colonial system. } \\
\text { The Native Societies for Providence (SIP) were } \\
\text { created by the colonist in } 1932 \text { along with six } \\
\text { other types of agricultural cooperatives. A } \\
\text { succession of programs launched by the French to } \\
\text { extend improved agricultural technologies to } \\
\text { rural farmers organized in cooperatives groups. }\end{array}$ & $\begin{array}{l}\text { Creation of research } \\
\text { centers. Guinea is the } \\
\text { third largest rice } \\
\text { producer in Africa. }\end{array}$ \\
\hline 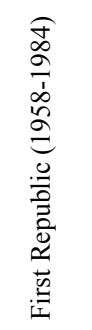 & $\begin{array}{l}\text { Socialism, } \\
\text { collectivization of } \\
\text { the means of } \\
\text { production }\end{array}$ & $\begin{array}{l}\text { 1. Reorganize the } \\
\text { properties of agrarian } \\
\text { cooperatives } \\
\text { 2. Increase rice } \\
\text { productivity } \\
\text { 3. Food self-sufficiency }\end{array}$ & $\begin{array}{l}76 \% \text { of the country's export was agricultural } \\
\text { products, mostly sold on the French markets. } \\
\text { Various farming schemes were introduced } \\
\text { (1960s-1970s), including highly mechanized } \\
\text { state-run farms and socialist farm complexes. All } \\
\text { land was declared to be the property of the state. } \\
\text { Direct investment in agricultural production and } \\
\text { marketing by the government. }\end{array}$ & $\begin{array}{l}\text { Creation of } \\
\text { mechanized brigades, } \\
\text { harnessed for } \\
\text { production; decrease } \\
\text { in agricultural } \\
\text { production; } \\
\text { abandonment of cash } \\
\text { crops. }\end{array}$ \\
\hline 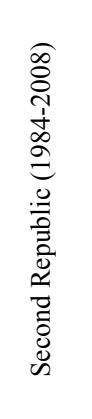 & $\begin{array}{l}\text { Economy } \\
\text { liberalization } \\
\text {-LPDA* } 1 \\
\text {-LPDA } 2\end{array}$ & $\begin{array}{l}\text { 1. Removal of marketing } \\
\text { standards } \\
\text { 2. Trade liberalization } \\
\text { 3. Removal of import } \\
\text { licensing } \\
\text { 4. Increase agricultural } \\
\text { production; decrease } \\
\text { imports }\end{array}$ & $\begin{array}{l}\text { Market liberalization measures; increased role of } \\
\text { commercial banks; devaluation of the national } \\
\text { currency. Investment in commercial production of } \\
\text { fruits and vegetables (Coastal and Southern } \\
\text { Foothills Zones), and of coffee and palm oil } \\
\text { (Forest Zone). Private firms organized farmers on } \\
\text { their periphery to produce commodities according } \\
\text { to their requirements. Letter of Agricultural } \\
\text { Development Policy in } 1992 \text { (LPDA1) and } \\
\text { (LPDA2) in 1998, were established. }\end{array}$ & $\begin{array}{l}\text { Investment in } \\
\text { agriculture; Increase } \\
\text { in annual growth of } \\
\text { GDP. Increase in rice } \\
\text { production; From } \\
2000 \text {, increase in } \\
\text { imports. Decrease in } \\
\text { the agriculture } \\
\text { growth rate and } \\
\text { cultivated areas. }\end{array}$ \\
\hline 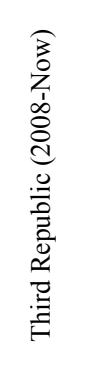 & $\begin{array}{l}\text { National Policy for } \\
\text { Agricultural } \\
\text { Development } \\
\text { (vision 2015) }\end{array}$ & $\begin{array}{l}\text { 1. Promote agricultural } \\
\text { entrepreneurship } \\
\text { 2. Improving market } \\
\text { access for agricultural } \\
\text { products } \\
\text { 3. Increase the production } \\
\text { of crops for export. }\end{array}$ & $\begin{array}{l}\text { (Ongoing activities) New agricultural technology } \\
\text { development; basic infrastructure and rural } \\
\text { finance development; Sustainable development of } \\
\text { rice production; Diversification of agricultural } \\
\text { production for greater food security; Promotion } \\
\text { of agricultural products for export and } \\
\text { agribusiness; Integration of sustainable natural } \\
\text { resource management; Strengthening of } \\
\text { institutions supporting agriculture }\end{array}$ & $\begin{array}{l}\text { Results } \\
\text { passed }\end{array}$ \\
\hline
\end{tabular}

Note. * Letter of Agricultural Development Policy.

Source: Author's compilation (Field Survey, 2012).

\subsection{Farmer Organizations in Guinea}

Farming has been practiced in Guinea over the last 300 years. Historical evidence suggests that farmer groups might be as old as sedentary agriculture. Most producer organizations in Guinea are in the first place, family base type organizations and management with voluntary membership and relative democratic control as mean essence. As depicted in Figure 1, individual farmers, from grass root level, seeking to get most benefit from their agricultural production and sustaining family livelihood, gather themselves into primary agricultural groups ranging from community-based associations to commodity based organizations. Community-based associations, 
sometimes called self-help groups, are built around customary principles and ideas of promoting and protecting individuals as well as collective well-being. Farmer organizations in Guinea may be broadly classified into primary organizations (production units) and rooftop farmer organizations. Grassroots farmers' groups do not always join rooftop farmers' organizations; they are farmers' associations with formal or informal agreement. Village associations usually operate separately and can even act as small rooftop organizations since they sometimes include small groups of farmers along with individual households. Inversely, some farmers directly join the rooftop organizations.

Rooftop farmers' organizations consist of unions and federations at prefectural and regional level and the national farmers' confederation. They are not directly involved in the production process and their main role is to provide funds, farming goods and technical counselling for peasants and to ensure the marketing of their products. Between rooftop farmers' organizations and the production units, there are intermediate farmer groups, specialized in marketing. Their relationship with production units is more consistent but limited to post-harvest operations (transport, husking of cereals, distribution, etc.). Some of these farmer groups play additionally the role of bridging production and rooftop organizations. These production groups, in seeking to represent a wider interest of the community in which they are based, form commodity based organizations, combining economic, social and political functions. While focusing more on their economic functions at regional level (federations), farmer organizations mirror the diversified farming systems and crops produced. They support the production and marketing of single cash crop by providing a number of services to their members, from inputs supply, marketing and market linkage development to lobbying and advocacy. The basic functions of farmer organizations performed at regional level are coordinated and strengthened at the national level by their national representation. This representation seeks, apart from members' interest defense, to ensure that farmers play a key role from early stages and participate a greater share to the country's socio economic development.

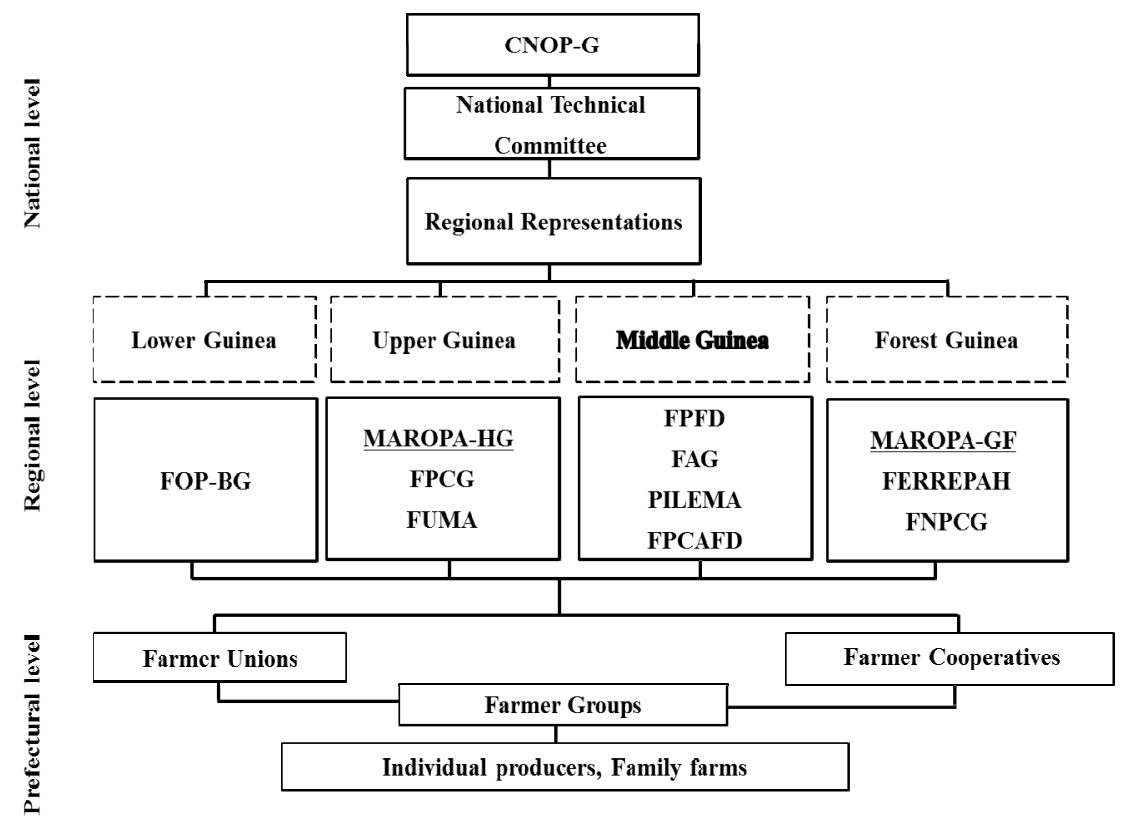

Figure 1. Structure of the Guinea National Confederation of Farmer Organizations

Source: Author's compilation (Field survey, 2012).

Note. CNOP-G: Guinea National Confederation of Farmer Organizations; FOP-BG: Federation of Lower Guinea Peasant Organizations; MAROPA-HG: Upper Guinea Professional Peasant Organizations' Chamber; FPCG: Guinea Cotton Growers' Federation; FUMA: Regional Federation of Vegetable Farmers; FPFD: Fouta Djallon Farmers' Federation; FAG: Regional Federation of Beekeepers; PILEMA: Fouta Djallon Fruit Farmers' Federation; FPCAFD: Fouta Djallon Federation of Coffee Growers; MAROPA-GF: Forest Guinea Professional Peasant Organizations' Chamber; FERREPAH: Regional Federation of Palm tree and Rubber tree Growers; FNPCG: National Federation of Coffee Growers. 
There are many farmers' organizations and cooperatives in Guinea that are active in agriculture, small scale production and processing. The National Confederation of Farmers' Organizations of Guinea (CNOP-G) was created in 2000. Throughout the country, the CNOP-G brings together producers organized into groups, unions and federations across the four natural regions. By early 2012, it comprised 15 federations with 191 federal unions and 6 non-federal unions, bringing together a total of 520,000 farmer members from all agricultural subsectors. These organizations are growing rapidly, and some are well organized into dynamic federations and unions (IFAD, 2012).

In Lower Guinea, farmers are represented by the Lower Guinea Farmer Organizations' Federation (FOP-BG). Farmers' Federations, unions and groups in Upper Guinea operate under the Upper Guinea Professional Peasant Organizations' Chamber (MAROPA-HG) and those in Forest Guinea are covered by the Forest Guinea Regional Chamber of Professional Peasants' Organization (MAROPA-GF). In Middle Guinea, the most important producer organizations are the Fouta Djallon Farmers' Federation, the Regional Federation of Beekeepers, and the Regional Federation of Vegetable Farmers (Figure 1). The CNOP-G is positioned as a key partner for the government and other development partners engaged in agriculture. It represents, coordinates, informs and mobilizes its members. It also defends their interests and engages in sector policy dialogue. With the overall objective evolving around increasing producers' income and livelihood improvement, these farmer organizations have since been attempting to define and develop appropriate strategies in a competitive open market and deliver much needed agricultural services to their membership.

Table 2. Brief presentation of the FPFD

\begin{tabular}{|c|c|}
\hline Name & Fouta Djallon Farmers' Federation \\
\hline Foundation & Established in Timbi Madina (Pita prefecture Middle Guinea) in 1992 \\
\hline Objective & Increase members' income \\
\hline Functions & $\begin{array}{l}\checkmark \text { Lobbying and negotiations, advocate for farmers and policies in their favor. } \\
\checkmark \text { Improving access to production input and adoption of high quality production technics } \\
\checkmark \text { Promote national and regional network for sharing information and best practices }\end{array}$ \\
\hline Main activities & $\begin{array}{ll}\checkmark & \text { Increasing availability and access of improved seeds, fertilizers and agricultural equipment } \\
\text { on credit basis } \\
\checkmark & \text { Marketing of farmers' produce and providing market incentives } \\
\checkmark & \text { Develop farmers training schemes and stimulate innovation } \\
\checkmark & \text { Infrastructure and community development }\end{array}$ \\
\hline Financing & Donors of funds (External), membership fee and members' contribution (Internal) \\
\hline Membership & $\begin{array}{l}29,907 \text { Members ( } 64 \% \text { of women) } \\
956 \text { Groups } \\
50 \text { Unions ( } 17 \text { of which are not formally registered) }\end{array}$ \\
\hline
\end{tabular}

Source: Author's compilation (Field Survey, 2012).

As presented in Table 2, the Fouta Djallon Farmers' Federation was created in 1992, initiated by small farmers, owners of family farms, as a response to their weak position in the market. By joining forces they could improve this position and obtain better prices and services and the commercialization of their produce. Driven by the goal of improving members' farm income, the Fouta Djallon Farmers' Federation is a member of the Guinean National Confederation of Farmers' Organizations (CNOP-G) and participates in the domestic and international market by providing inputs to its members and marketing their product. Induced by local and external initiatives calling for a greater role in the development process, the federation brings together producers organized along crops value chain mainly potatoes, onions, tomato, rice and maize. The FPFD is one of the most prominent and successful farmers' organizations in Guinea. The potato chain holds $75 \%$ of input credit and is the main grown cash crop with yearly production amounted to 16,000 t (FPFD, 2011), exclusively produced in the Fouta Djallon region. 


\section{Materials and Methods}

\subsection{Study Area and Data Collection}

The study was conducted in three districts of the Fouta Djallon highlands in the Middle Guinea (Figure2). The study sites are located in the Fouta Djallon region in the middle of the central plateau, between $11^{\circ} 05^{\prime}$ and $11^{\circ} 10^{\prime}$ latitude north and $12^{\circ} 13^{\prime}$ and $12^{\circ} 22^{\prime}$ longitude west. The areas have the same geomorphological divisions of the Fouta Djallon. This region is distinguished by low hills attesting ancient planation surfaces, and also a resistant surface structure of indurated sandstone. The chemical fertility depends on the degree of weathering; the high concentration of gravel is responsible for the high agricultural value to farmers of some soils since their water filtration and porosity are very suitable to the growth of upland rice and other crops. In general the aspect is similar over the whole Fouta Djallon. Systems of production are grouped into two: intensive farming within infields and extensive farming within outfields (Garvey, 1987). Besides these two agro-systems there is agroforestry where fruit trees and/or timbers are planted. The main occupation of the people in these areas is farming and trading. The major food crops grown are rice, potato, cassava, maize, onion, tomato, fonio, peanut and other vegetables. Potato is the most marketed cash crop at both large and small scale with most of its value chain functions performed by producers themselves.

The basic information for the analysis was obtained from primary data collected from potato producers in three major potato producing districts of the Fouta Djallon highlands (Figure 2), in the Middle Guinea: Timbi Madina, Timbi Touny (Pita prefecture) and Hafia (Labe prefecture). The region was purposively chosen because it is the major potato producing area in Guinea, with identifiable producer groups and most importantly, it has one of the successful farmer organizations, the Fouta Djallon Farmers' Federation. The study areas were selected purposively based on their potato productivity to obtain a sample of individual producers; this was also driven by contextual circumstances and the need to ensure that an important number of potato growers would be identified in a random sample. To obtain a sample of members of producer groups, a random sample of registered farmers of the Fouta Djallon Farmers' Federation (FPFD) was drawn from a complete list in each area and farmers were then selected from among the listed members. A comprehensive and structured questionnaire was used to collect data from members and non-members of farmers' groups among the smallholder potato producers. Face-to-face interviews were conducted with 90 potato producers to collect information on the farm economy, farming practices, as well as the social and economic characteristics of the farm household. However, due to missing data, the effective sample used for the empirical analysis was 85 farmers (56 farmers' group members and 29 non-members). In addition, key informants and focus group discussions were conducted; secondary data was synthesized from literature review and reports from the Ministry of Agriculture and the Guinea National Confederation of Farmers' Organizations (CNOP-G) among other sources.

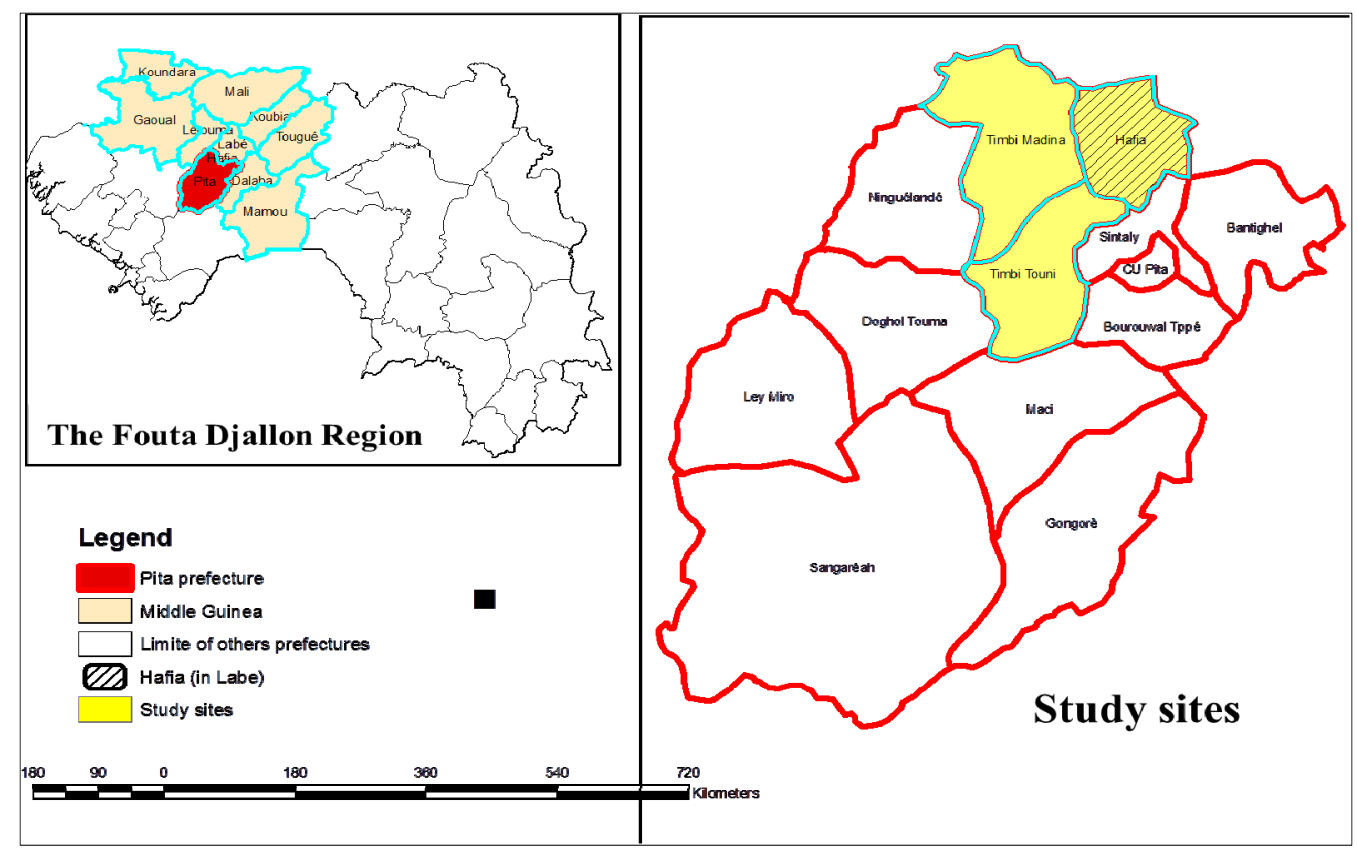

Figure 2. Location of the study sites 


\subsection{Econometric Model}

Estimating the impact of group membership on producers farm income might be subject to selection bias resulting from unobserved factors influencing not only the producers willingness to join the farmers' organization, but also their performance. It is therefore necessary to efficiently address the issue of selection bias (Qaim \& de Janvry, 2005). Selection bias is introduced on observables if, for example farmers who are wealthier or whose yields are higher in the absence of group membership are also likely to join. Unobserved variables such as inherent management ability of the farmer can also affect both the decision to join the farmers' group and the farm income. In that case, Ordinary Least Square (OLS) estimation would lead to biased parameter estimates as running a simple regression of farm income on a dichotomous variable that indicates group membership will overestimate the impact of group membership on farm income. As originally conceptualized by Ravillion (1994), the dilemma of assessing impacts is essentially one of missing observations. For this current study, to control for potential selection bias, we estimated the Heckman two-step approach; this approach is known as one of the most widely used to correct sample selection bias (Greene, 2008). In this model, an auxiliary probit regression is used to obtain the probability of participation in farmers' group and derive the inverse Mill's ratio, which is then included as a selectivity correction in the outcome equation on income. Esham et al. (2006), in a study on contract farming in Sri Lanka, used the computation of the inverse Mill's ratio to estimate the impact of contract farming. This analysis is implemented as a maximum likelihood and identification is provided by the inclusion of a variable in the selection model that is not found in the outcome equation.

The probit model used to identify the factors that influence the decision of producers growing potato to join farmers' groups, is expressed below and is used as the selection equation.

$$
P_{(1,0)}=\alpha Z_{i}+\varepsilon_{i}
$$

Where $\alpha=$ constant, $P$ is a dummy variable ( 1 for group members and 0 for non-members) $Z_{\mathrm{i}}$ is the set of respective observed factors expected to influence the decision to join farmers' groups and $\varepsilon_{\mathrm{i}}=$ random error term, assumed to be normally distributed to take account of unobserved factors that influence decision to join farmers' groups.

As mentioned above, from the selection equation, the inverse Mill's ratio $\left(M_{\mathrm{i}}\right)$ is derived and then inserted into the second stage outcome equation (expressed below) to estimate the effect of group membership.

$$
Y_{i}=\beta X_{i}+\varphi P_{i}+\delta M_{i}+\mu_{i}
$$

Where $Y_{i}$ is the impact outcome variable (gross farm income in $\mathrm{fg} / \mathrm{ha}$ ) for potato producers; $X_{i}$ is a vector of independent variables affecting farm income; $P_{i}$ is a binary variable representing group membership; $\beta, \varphi$ and $\delta$, are parameter vector to be estimated; and $\mu_{\mathrm{i}}$ a normally distributed random error term.

For the empirical analyses, we included three categories of variables that are expected to influence farmers' group membership decision as well as determine the impact of group membership on farm income.

Table 3 gives a detail description of the variables included in the above mentioned models. Variables used in the analyses include indicators of household wealth, such as farm size, ownership of farm land and income derived from non-farm activities. Household wealth is expected to enable farmers to overcome the barriers and obstacles to meeting group membership requirement as well as production cost. Farm size is included to represent farmers' physical production resource. As effective utilization of farm land requires the application of appropriate farm practices and inputs, in the absence of more means of assessing effectiveness, this variable would either be positively or negatively related to group membership and the overall farm productivity. Off-farm income can help diminish on-farm constraints and serve as alternative capital inputs and would encourage participation in farmers' groups.

A second set of variables includes indicators of capability and information, such as education, extension service, farm credit and membership in farmers' groups. Used as a proxy for human capital endowment, education level of farmers (years of formal schooling of the household head) is important in the decision-making process. Access to farm credit and extension workers capture farmers access to these services and the associated costs and difficulties that influence group membership; they are expected to have a positive effect on farmers' decision to join farmers' organizations. Group membership is expected to have a positive effect on farmers' income as it may increase market participation as well as linking producers to potential markets. Fischer et al. (2012a) argue that membership of farmers' organizations can benefit producers by reducing high transaction cost associated with smallholder agriculture.

The third category of variables refers to indicators of socio demography like family size, gender, age of the head of household, marital status, family labor as detailed in Table 3. Family size for instance accounts for the supply of 
family labor and may have a significant impact on group membership if it provides labor efficiently. Gender of the household head is used to capture the differences in preferences between male and female headed households. Female farmers are expected to have higher chances of joining farmers' groups while male headed household is less likely to participate in farmer groups. This may be because of pro-gender policies and the increasing efforts to mainstream gender in rural farmers' groups. The age of farmers is used to measure the behavioral pattern of the respondents and is expected to be positively related to participation in farmer groups. With the kind of labor-intensive farming system that prevails in the study area, labor availability is an important factor. Increase in labor use may enhance farm production which in turn may increase the share of output sold, hence incomes. The market price of potato may have a significant impact on farmers' income; it can also show the performance of the farmers' group in paying higher market price to its membership. This variable is expected to be positively related to producers' farm income. All else being equal, these factors may shape the household decision but also influence producers' farm income as well as access to productive resources.

Table 3. Definition of explanatory variables used in the regression models

\begin{tabular}{|c|c|c|c|}
\hline Variables & Definition & Mean & Std. Dev \\
\hline Group membership & Membership in farmer group ( $1=$ yes; $0=$ no $)$ & 0.66 & 0.477 \\
\hline Age & Farmer's actual age (years) & 50.85 & 10.94 \\
\hline Gender & Respondent's gender $(1=$ male; $0=$ female $)$ & 0.40 & 0.49 \\
\hline Marital status & Whether respondent is married $(1=y e s ; 0=$ no) & 0.94 & 0.24 \\
\hline Education & Actual level of schooling (years) & 2.76 & 3.86 \\
\hline Family size & Number of household members (persons) & 7.34 & 3.22 \\
\hline Family labor & Family members working on the farm (persons) & 4.58 & 2.30 \\
\hline Land ownership & Whether respondent owns farm land $(1=y e s ; 0=$ no) & 0.68 & 0.47 \\
\hline Farm size & Household's total arable land (ha) & 1.51 & 1.52 \\
\hline Potato area & Potato production area (ha) & 0.89 & 0.72 \\
\hline Distance to road & Distance from farm to main road $(\mathrm{km})$ & 1.03 & 1.26 \\
\hline Labor used & Hired labor (man day/ha) & 199 & 317 \\
\hline Extension access & Access to extension service $(1=\mathrm{yes} ; 0=$ no $)$ & 0.73 & 0.447 \\
\hline Distance to market & Distance to primary market $(\mathrm{km})$ & 4.44 & 2.32 \\
\hline Share of potato sold & Quantity of potato sold to total harvested ( percent) & 1.94 & 1.98 \\
\hline Potato price & Potato market price (fg/kg) & 4,480 & 860.81 \\
\hline Farm income & Gross farm revenue (fg/ha) & $22,858,405$ & $17,438,460$ \\
\hline Credit access & Access to farm inputs credit $(1=$ yes; $0=$ no $)$ & 0.54 & 0.50 \\
\hline Off farm income & Income from non-farm activities (fg) & $2,851,300$ & $3,782,486$ \\
\hline
\end{tabular}

\section{Results and Discussion}

\subsection{Descriptive Data Analysis}

Descriptive statistics for the sample farmers are presented in Table 4 . The average farm size of our sample farmers is 1.5 ha (Table 3), but only 0.89 ha is dedicated to potato production on the average; about $68 \%$ of the farmers owned their farm land. This closely mirrors the situation of farmers in Guinea where the average farm size is 0.5 ha. The majority of the farmers are female $(60 \%)$ and the sample farmers are 50 years old on average with about $94 \%$ of them being married. With respect to farmers access to extension service and farm credit, overall, $73 \%$ and $54 \%$ of them reported to have access to the services respectively.

Comparing farmer group members and non-members, a few differences with respect to socioeconomic household characteristics can be observed between the two groups. Although for the majority of the household's socioeconomic and demographic characteristics as well as household resource endowment, no major difference was revealed, a few significant correlations were established. Generally, results in Table 4 indicate that household 
characteristics across the two groups were not statistically significant except in terms of age, access to extension services and access to credit. For group members, the average age of household head was 53.05 years whereas their counterpart had an average of 46.59 years. Results show a statistically significant difference $(p<0.01)$; it has been established that this variable is a key determinant of behavioral patterns of farm households (Bembridge, 1984). Young farmers are expected to be more technically constrained than older farmers who are perceived to have acquired experience on farming and resources. Similarly, there was a significant difference for credit and extension service access. More producers with membership in farmers' group have access to farm credit and assistance from extension workers. Namely, $94.6 \%$ and $75 \%$ of group members respectively have access to extension service and credit whereas for their counterpart, figures are different; $31 \%$ have access to extension workers and only $13.8 \%$ of non-members have access to credit. Access to credit measures whether farmers had access to agricultural input and/or equipment on credit for the facilitation of production. Agricultural training and extension services are provided by governmental entities and other institutions. A larger share of our sample farmers benefited those services through their membership in farmers' groups. In fact, only a very small percentage $(5.4 \%)$ of members of farmers' groups did not have access to services from extensions workers. Finally, results depicted in Table 4 revealed that the agricultural resource endowment is not a decisive factor in producers participation in farmers' groups. No significant difference was found between the two categories with respect to family labor, farm size, cultivated potato area, off farm income amongst others.

Table 4. Descriptive statistics of respondents

\begin{tabular}{|c|c|c|c|c|c|}
\hline \multicolumn{2}{|c|}{ Continuous variables } & Group members & Non members & t-statistic & p-value \\
\hline \multicolumn{2}{|l|}{ Age } & 53.05 & 46.59 & 2.678 & $0.009^{* * *}$ \\
\hline \multicolumn{2}{|l|}{ Education } & 2.54 & 3.21 & -0.758 & 0.450 \\
\hline \multicolumn{2}{|l|}{ Family size } & 7.57 & 6.90 & 0.915 & 0.363 \\
\hline \multicolumn{2}{|l|}{ Family labor } & 4.61 & 4.52 & 0.169 & 0.866 \\
\hline \multicolumn{2}{|l|}{ Farm size } & 1.46 & 1.61 & -0.433 & 0.666 \\
\hline \multicolumn{2}{|l|}{ Potato area } & 0.92 & 0.83 & 0.527 & 0.600 \\
\hline \multicolumn{2}{|c|}{ Distance to road } & 1.10 & 0.89 & 0.724 & 0.471 \\
\hline \multicolumn{2}{|c|}{ Hired labor used } & 210.67 & 176.97 & 0.463 & 0.645 \\
\hline \multicolumn{2}{|c|}{ Distance to market } & 4.49 & 4.35 & 0.269 & 0.789 \\
\hline \multicolumn{2}{|l|}{ Potato price } & 4,557 & 4,332 & 1.144 & 0.256 \\
\hline \multicolumn{2}{|c|}{ Off farm income } & $3,109,821$ & $2,352,086$ & 0.874 & 0.384 \\
\hline \multicolumn{2}{|c|}{ Categorical variables } & $\%$ & $\%$ & $X^{2}$ statistic & p-value \\
\hline \multirow{2}{*}{ Gender } & Male & 33.9 & 51.7 & \multirow{2}{*}{2.521} & \multirow{2}{*}{0.161} \\
\hline & Female & 66.1 & 48.3 & & \\
\hline \multirow{2}{*}{ Marital status } & yes & 94.6 & 93.1 & \multirow{2}{*}{0.082} & \multirow{2}{*}{1.000} \\
\hline & no & 5.4 & 6.9 & & \\
\hline \multirow{2}{*}{ Land owned } & yes & 62.5 & 79.3 & \multirow{2}{*}{2.491} & \multirow{2}{*}{0.144} \\
\hline & no & 37.5 & 20.7 & & \\
\hline \multirow{2}{*}{$\begin{array}{l}\text { Extension } \\
\text { access }\end{array}$} & yes & 94.6 & 31 & \multirow{2}{*}{39.166} & \multirow{2}{*}{$0.000 * * *$} \\
\hline & no & 5.4 & 69 & & \\
\hline \multirow{2}{*}{ Credit access } & yes & 75 & 13.8 & \multirow{2}{*}{28.826} & \multirow{2}{*}{$0.000 * * *$} \\
\hline & no & 25 & 86.2 & & \\
\hline
\end{tabular}

Note. $* * *$ indicates significance level at $1 \%$.

Source: Author's survey (2012).

The estimation of crop profitability between the two categories of producers is presented in Table 5. 
Based on the net farm profit, profitability estimation between farmers' group members and non-members shows some significant differences. As depicted in Table 5, the highest cost for our sample farmers is on potato seed and fertilizer accounting respectively for about $51 \%$ and $23 \%$ of the total farm production cost. The net farm profit is the return to land, agricultural capital as well as production and labor cost. The cost on fertilizer is considerable and higher $(\mathrm{p}<0.05)$ for non-members accounting for about $30 \%$ against $16 \%$ for members. This is mainly because potato producers with membership in farmers' groups have access to readily available farm input at a rather lower cost than non-members. This could be explained by the bulk purchasing of farm input by producers through their membership in the farmers' group. Because of particularly high costs on seed and fertilizer, there is a considerable difference in farm revenue; the net farm profit is higher $(p<0.05)$ for members than non-members.

More, due to high input cost, the ratio of revenue to cost and the ratio of net farm profit to revenue are significantly different between the two groups ( $\mathrm{p}<0.10$ and $\mathrm{p}<0.01$ respectively). They are greater for group members than for non-members; overall, group members realize a farm profit of nearly twice than that of non-members. This is certainly due to the support they receive from their membership in farmers' group. However, the total farm management and production cost is nearly the same between members and non-members of farmers' group. The cost on seed, farm manure, labor and machinery as well as the fixed input cost present no significant difference between the two groups. Farmers in the study area in general, in addition to the high cost of farm input, are constrained to access to farm input and agricultural equipment.

Table 5. Profitability estimation of potato production per ha

\begin{tabular}{lllll}
\hline Characteristics & Group members & Non members & t-statistic & p-value \\
\hline A. Farm revenue (fg) & $25,632,638$ & $17,501,264$ & 2.078 & $0.041^{*}$ \\
B. Variable input cost (fg) & & & & 0.108 \\
$\quad$ Seed cost & $5,019,999$ & $3,580,126$ & 1.624 & $0.014^{* *}$ \\
$\quad$ Fertilizer cost & $1,444,761$ & $2,368,444$ & -2.515 & 0.559 \\
$\quad$ Farm manure cost & 857,832 & 728,534 & 0.587 & 0.753 \\
$\quad$ Labor cost & $1,109,448$ & $1,021,088$ & 0.315 & 0.353 \\
$\quad$ Machinery cost & 180,238 & 107,042 & 0.934 & 0.571 \\
$\quad$ Total & $8,612,279$ & $7,805,234$ & 0.570 & 0.512 \\
C. Fixed input cost (fg) & 199,797 & 148,545 & 0.658 & 0.554 \\
D. Production cost (B+C) & $8,812,076$ & $7,953,779$ & 0.595 & $0.017^{* *}$ \\
E. Net farm profit (A-D) & $16,820,562$ & $9,547,484$ & 2.436 & $0.071^{*}$ \\
Ratio of revenue to cost (A/D) & 3.53 & 2.69 & 1.828 & $0.007^{* * *}$ \\
Ratio of net farm profit to revenue (E/A) & 0.62 & 0.47 & 2.758 \\
\hline
\end{tabular}

Note. ${ }^{* *}, * *, *$ indicate significance level at $1 \%$ and $5 \%$ and $10 \%$ respectively, Franc Guinéen (Fg): unit of Guinean currency.

Source: Author's survey (2012).

\subsection{Determinants of Group Membership}

A probit model was used to explain variables assumed to influence the decision of producers to join the farmers' group. Among the variables described above, only age, gender, education, farm size, extension service, access to credit and off farm income had significant marginal effect on marginal probability of participating in farmer groups. The results are presented in Table 6.

The estimation results indicate that participation in farmer groups is strongly associated with the households' socioeconomic and demographic characteristics. Holding other factors constant, positive significant coefficient of the age of the household head implies that per unit increase in the age of the farmer increases the probability of participation in farmer groups by $0.59 \%$. Participation in farmers groups increases with age; older farmers are more likely to join the farmers' group. The labor-intensive nature of potato production in the study area would 
have prompted older farmers to join the farmers' group. On the other hand, the findings support the role of age in resource ownership; in the study area, older household heads have better access to land resource which is an important factor of production unlike the younger household heads that mainly rely on inherited land. This means that young farmers are less likely to join and participate in farmer groups because they are forced to wait longer before they own ample production resources which could enable them to participate in farmer group activities.

Table 6. Determinants of membership in farmer's group

\begin{tabular}{lllll}
\hline Variables & Coefficients & Std. Error & Marginal effect & p-value \\
\hline Age & 0.060 & 0.029 & 0.0059 & $0.041^{* *}$ \\
Gender & -1.651 & 0.887 & -0.1619 & $0.063^{*}$ \\
Marital status & -1.477 & 1.102 & -0.1449 & 0.180 \\
Family size & 0.050 & 0.122 & 0.0049 & 0.681 \\
Education & -0.133 & 0.077 & -0.0131 & $0.084^{*}$ \\
Land ownership & 0.333 & 0.696 & 0.0327 & 0.632 \\
Farm size & 0.506 & 0.293 & 0.0496 & $0.084^{*}$ \\
Extension service & 3.909 & 1.149 & 0.3834 & $0.001^{* * *}$ \\
Distance to road & 0.434 & 0.355 & 0.0426 & 0.221 \\
Credit access & 2.768 & 1.019 & 0.2716 & $0.007^{* * *}$ \\
Off farm income & $3.60 \mathrm{e}-07$ & $1.40 \mathrm{e}-07$ & $3.53 \mathrm{e}-08$ & $0.010^{* *}$ \\
Constant & -6.150 & 2.219 & & 0.006 \\
$\mathrm{~N}$ & & & & 85 \\
LR chi2(11) & & 75.28 & Log likelihood & -16.9159 \\
Prob $>$ chi2 & & 0.0000 & Pseudo R2 & 0.6899 \\
\hline
\end{tabular}

Note. $* * *, * *, *$ indicate significance level at $1 \%$ and $5 \%$ and $10 \%$ respectively.

Source: Author's survey (2012).

Gender is significant and negatively related to participation in farmer groups. This is an important indicator of household decision making whereby in traditional setup, key decisions in a household are made by men. Male-headed households are less likely to join farmers groups; all other variable held constant, the probability of participation in farmer groups is $16.19 \%$ lesser for male than female. A plausible explanation for this could be that potato production in the study area was traditionally regarded as a women activity. This also depicts preferences of male heads and female household heads. Results in Table 6 show that male headed households are less likely to join groups (by about $16.19 \%$ ). The findings agree with observation of Musyoki et al. (2013) that gender is a crucial determinant of household decision to join community associations.

Education of household head was significant and negatively related to group membership and revealed the tendency of educated farmers to staying away from farmers groups by $1.3 \%$. The reasons explaining this could probably be that the majority of educated farmers in the study area are better off farmers, they are usually government workers who are involved in farming and they have better access to farm inputs and other services.

Although the magnitude of its effect is rather small, an increase in farm size increases the probability of group participation by $4.96 \%$. This is particularly important as stated before, farmers are in their majority resource-poor; cultivating on larger farm sizes requires more resources and investment; therefore participation in farmer groups is in most cases the ultimate way of overcoming such obstacles.

Access to extension service has statistically significant and positive effects on group membership; it increases group participation by $38.34 \%$. This is probably because as agricultural extension agents are better informed, they are likely to discuss with farmers about membership in farmers groups and influence their decision about group membership. The more the extension contact with smallholder farmers, the better their involvement in farmer group and the better productivity increases. Extension service is an important source of farming information and advice to smallholder farmers (Enki et al., 2001). 
The statistically significant coefficient of credit in the results indicates that access to credit influences the decision of producers to join farmer groups. Per unit increase in farmer access to credit increases probability of participation by $27.16 \%$, all else being equal. This implies that a farmer that has access to credit is more likely to join farmers' group. Given that poor households, in their quest for membership in farmers' groups, experience difficulties such as compliance with the group membership demands, access to farm credit may be an incentive for group membership. In a similar study, Asante et al. (2011) found that access to credit positively influenced farmers' decisions to join farmer based organizations in Ghana. Access to credit helps to better strengthen the capacity of such households hence facilitating membership into farmers' groups.

Similarly, income from non-farm activities also enables the capabilities of producers to meet group membership requirement given the poor household resource endowment as a whole, hence facilitating group membership. Generally, producers tend to join farmers' groups in order to benefit from the advantages this could give in terms of access to farm inputs and output market.

\subsection{Effects of Membership in Farmers' Group on Farm Income}

After identifying the factors that influence the decision of the sample farmers to join farmers' groups, we explore the effects of group membership on farmers' income. Potato producers join the farmers' group mainly to benefit agricultural services (farm inputs, farm tools, training, etc.) but also they expect their membership to benefit them in terms of higher farm incomes derived from potato production.

Results presented in Table 7 show the results of the regression model on farm income. Results revealed that five variables were significant in explaining the effects of group membership on farmers' income and these variables are group membership, labor used, cultivated potato area, potato price and the share of potato sold.

Table 7. Effect of farmer group membership on farm income

\begin{tabular}{llll}
\hline Variables & Coefficients & Std. Error & p-value \\
\hline Constant & $2,812,865$ & $1.49 \mathrm{e}+07$ & 0.851 \\
Group membership & $7,413,487$ & $3,817,742$ & $0.056^{*}$ \\
Age & $-37,421.92$ & $176,719.7$ & 0.833 \\
Education & $186,767.1$ & $479,573.9$ & 0.698 \\
Labor used & $14,677.29$ & $5,687.39$ & $0.012^{* *}$ \\
Family labor & $-329,451.2$ & 781,430 & 0.675 \\
Potato area & $5,719,886$ & $3,371,019$ & $0.094^{*}$ \\
Distance to market & $-808,928.3$ & $772,860.4$ & 0.299 \\
Potato price & $1,310.738$ & $2,093.4$ & $0.053^{*}$ \\
Share of potato sold & $4,140,134$ & $1,267,374$ & $0.002^{* * *}$ \\
Inverse Mill's ratio & 206.12 & 237.97 & 0.389 \\
$\mathrm{~N}$ & & & 85 \\
$\mathrm{~F}(10,74)$ & 3.36 & R-squared & 0.3122 \\
Prob > F & 0.0012 & Adj R-squared & 0.2193 \\
\hline
\end{tabular}

Note. $* *, * *, *$ indicate significance level at $1 \%$ and $5 \%$ and $10 \%$ respectively.

Source: Author's survey (2012).

Results of the model confirm a statistically significant and positive effect of group membership $(p<0.10)$ on producers' farm income (dependent variable). From the auxiliary probit regression used in our analysis to obtain the probability of participation in farmers' groups, the inverse Mill's ratio was computed and then included as a regressor into the second stage outcome equation. This term corrects for possible selection bias and yields consistent estimates in the income model. As shown in Table 7 the $\mathrm{F}$ test of the regression is significant and the inverse mills ratio was not significant, indicating that there was no selection bias. By participating in farmers' group, farmers could significantly increase their income from potato production. For instance, group membership on average, was able to increase the participant's farming income by $7,413,487 \mathrm{fg}$ per cultivation. 
Another important factor that influences farmers' income is the share of potato sold $(\mathrm{p}<0.01)$; farmers will try to maximize their income by increasing their share of potato sold. It is important to highlight that higher income from potato production can be a result of several factors including higher prices, larger shares of output sold, or better yields. Our results show that potato price and share of potato sold are statistically significant and have a positive effect on farm income at $10 \%$ and $1 \%$ significance level respectively. Farmers who have access to higher potato market price are able to secure higher income. Our results backed finding by Bernard et al. (2008) that farmers may gain from increased price levels for farm products or lower price levels for supplies. According to the model estimates, an increase by 1 ha in total potato cultivated area, would lead to a 5,719,886 fg increase in farm income. This could be explained by the effective utilization of farm land which may enhance production and consequently marketable surplus thereby increasing farming income. This is in line with the finding by Randela et al. (2008) that farmers with larger farms have a higher probability of selling more of their output because large farms have potential to increase marketable surplus. Similarly, labor use also has a significant impact on farm income $(\mathrm{p}<0.05)$, indicating that all other factors held constant, farmers who use more labor, may obtain higher farm income. Under the kind of labor-intensive farming system that prevails in the study area, labor availability and use may significantly contribute to increasing farm income by enhancing farm production.

\section{Conclusion and Recommendations}

Farmers' organizations are indispensable in facilitating and enhancing farm production and incomes of smallholder farmers in Guinea. Their potential for realizing pro-poor economic grow can no longer be underestimated. However, despite their growing importance, studies on farmers' organizations in Guinea are limited and there is still very little in the scientific literature about the importance and impact of farmers' organizations in Guinea. This study was set out to fill in the gap on assessing the effects of farmers' organizations in Guinea. In this respect, two key issues were addressed in the current research: the factors affecting the decision of farmers to join farmers' groups and the effects of group membership on farm income.

Results from our empirical study revealed the following. Firstly, the household resource endowments of the sample farmers present no significant difference between group members and non-members. Secondly, variables that significantly influenced membership into farmer groups are age of the household head, gender of the farmer, education level, land ownership, extension service, credit access and income from non-farm activities. Age of the farmer, land ownership, extension service, credit access and off-farm income positively influenced group membership whereas gender (if farmer is male) and education level had a negative effect on farmers' decision to join farmer groups. Thirdly, shedding light on the factors affecting farm income, results of the regression model showed that group membership was significant and positively associated with farm income. The results also point that farm income is positively and significantly affected by labor used, potato price, share of potato sold and cultivated potato area. Furthermore, the analyses on the profitability estimation revealed that group members were able to earn significant higher net farm profit than non-members; the results show that there was a statistically significant difference in terms of net farm income between farmers' group members and non-members.

These outcomes support the assertions in the farmer organizations literature that group membership has the potential to benefit farmers by increasing their incomes and that farmer organizations provide a good platform for the provision of farm production inputs and marketing of output; this can immensely enhance farm productivity and increase farm income thereby contributing to the reduction of poverty.

From a policy implication perspective, this is crucial since the integration of smallholder farmers in the market-oriented production through farmer organizations can transform the rural economy through increased incomes. Improving agricultural productivity being one of Guinea's agricultural policy priorities, farmers' organizations can, in this respect, play an important role in improving the level of agricultural technology adoption and achieving better growth in the sector. In order to reduce poverty and improve food security in rural Guinea, there is a need to support and promote farmer organizations. Such approach should also be reinforced with investment in agricultural and transport infrastructure if farmer organizations are to efficiently play their role and become market outlet for smallholder farmers in Guinea.

Finally, despite the limited scope of the study as the results are based on a relatively small sample size, the findings of this paper contribute immensely to the limited body of knowledge on farmers' organizations and their benefits in Guinea. In particular, our findings suggest that providing support to farmers' organizations is important for the intensification and development of smallholder agriculture in Guinea through provision of improved farm inputs and output marketing. Since farmers' organizations are assuming much significant role for smallholder farmers in Guinea, we believe further research is needed to know more about the pathways of the 
impact of farmers' organizations on smallholder agriculture in Guinea. In particular, the key research areas would be on the desired impact of farmers' organizations on their members' economic activities, bargaining power and commercialization by farmers in Guinea. It would also be essential for future research to focus on the impact of farmers' organizations on the adoption of improved agricultural technologies by smallholder farmers in Guinea.

\section{References}

African Development Bank. (2011). Guinea, Country Strategy Paper (2012-2016).

Asante, B. O., Sefa, V. A., \& Sarpong, D. B. (2011). Determinants of small scale farmers' decision to join farmer based organizations in Ghana. African Journal of Agricultural Research, 6(10), 2273-2279. http://dx.doi.org/10.5897/AJAR12.667

Bachke, M. E. (2009). Are farmers' organizations a good tool to improve small-scale farmers' welfare? Paper presented at Nordic Conference in Development Economics, Oscarsborg, Norway, June 18-19, 2009. Retrieved from http://www.umb.no/statisk/ncde-2009/maren_e_bachke.pdf

Bah., A. M. (1998). Business Management of Agricultural Cooperative Corporations in Guinea and Japan (Ph.D. thesis). The United Graduate School of Tottori University, Japan.

Bembridge, T. J. (1984). A systems approach study of agricultural development problems in Transkei (PhD thesis). University of Stellenbosch, Bloemfontein, South Africa.

Bernard, T., \& Spielman, D. (2009). Reaching the Rural poor through Rural Producer Organizations. A study of Agricultural Marketing Cooperatives in Ethiopia. Food Policy, 34(1), 60-69. http://dx.doi.org/10.1016/j.foodpol.2008.08.001

Bernard, T., Seyoum Taffesse, A., \& Gabre-Madhin, E. (2008). Impact of Cooperatives on Smallholders' Commercialization behavior: Evidence from Ethiopia. Agricultural Economics, 39(2), 147-161. http://dx.doi.org/10.1111/j.1574-0862.2008.00324.x

Enki, M., Belay, K., \& Dadi, L. (2001). Determinants of Adoption of Physical Soil Conservation Measures in Central Highlands of Ethiopia: The Case of three Districts of North Shewa. Agrekon, 40(3), 293-315. http://dx.doi.org/10.1080/03031853.2001.9524955

Esham, M., Usami, K., Kobayashi, H., \& Matsumura, I. (2006). An Economic Study of Contract Farming in the Fruit and Vegetable Industry in Sri Lanka: A Case Study of Gherkin (Cucumis sativus) Production. Journal of Rural Problems, 42(1), 14-23. http://dx.doi.org/10.7310/arfe1965.42.14

Fischer, E., \& Qaim, M. (2012b). Gender, Agricultural Commercialization, and Collective Action in Kenya. Food Security, 4, 441-453. http://dx.doi.org/10.1007/s12571-012-0199-7

Fischer, E., \& Quaim, M. (2012a). Linking smallholders to markets: Determinants and impacts of farmer collective action in Kenya. World Development Journal, 40(6), 1255-1268. http://dx.doi.org/10.1016/j.worlddev.2011.11.018

Fischer, E., \& Quaim, M. (2013). Smallholder farmers and collective action: What determines the intensity of participation? Journal of Agricultural Economics, 65(3), 683-702. http://dx.doi.org/10.1111/1477-9552.12060

Fouta Djallon Farmers' Federation (FPFD). (March, 2011). General Assembly Report (French).

Garvey, W. (1987). Agricultural credit and cooperatives in Guinea. National Cooperative Business Association Washington, D.C. 20005. Retrieved from http://pdf.usaid.gov/pdf_docs/PNABJ352.pdf

Greene, W. H. (2008). Econometric Analysis (6th ed.). Prentice-Hall, New Jersey.

Hazell, P., Poulton, C., Wiggins, S., \& Dorward, A. (2010). The future of Small farms: Trajectories and policy priorities. World Development, 38(10), 1349-1361. http://dx.doi.org/10.1016/j.worlddev.2009.06.012

IFAD. (2010). Rural Poverty in Guinea. International Fund for Agricultural Development.

IFAD. (August, 2012). Enabling poor rural people to overcome poverty in Guinea. International Fund for Agricultural Development.

Millie, B. A., Nyakuni, A., \& Gideon, S. (2006). Strengthening Farmer's Organizations: RELMA's experience in Eastern and Southern Africa. ICRAF Working Paper No. 23.

Musyoki, J. K., Mugwe, J., Mutundu, K., \& Muchiri, M., (2013). Determinants of Household Decision to join 
Community Forest Associations: A Case Study of Kenya. ISRN Forestry, 2013. http://dx.doi.org/10.1155/2013/902325

Mwaura, F. (2014). Effect of Farmer Group Membership on Agricultural Technology adoption and Crop Productivity in Uganda. African Crop Science Journal, 22(Supplement s4), 917-927

Olwande, J., \& Mathenge, M. (2012). Market participation among Poor Rural Households in Kenya. Contributed paper, International Association of Agricultural Economists (IAAE) Triennial Conference, Foz do Iguaçu, Brazil. August 18-24, 2012.

Oyeyinka, R. A., Ayansina, S. O., \& Adamu, C. O. (2009). Effect of Farmers organization on Agricultural Technologies Development in Afijio Local Government areas of Oyo State, Nigeria. OIDA International Journal of Sustainable Development, 5(11), 43-50. Retrieved from http://www.ssrn.com/link/OIDA-Intl-Journal-Sustainable-Dev.html

Qaim, M., \& de Janvry, A. (2005). Bt Cotton and Pesticide use in Argentina: Economic and Environmental Effects. Environment and Development Economics, 10, 179-200. http://dx.doi.org/10.1017/S1355770X04001883

Randela, R., Alemu, Z. G., \& Groenewald, J. A. (2008). Factors enhancing Market Participation by Small-scale Cotton Farmers. Agrekon, 47(4). http://dx.doi.org/10.1080/03031853.2008.9523810

Ravallion, M. (1994). Poverty comparisons. Fundamentals of Pure and Applied Economics (Vol. 56). Harwood Academic, Chur, Switzerland.

Rosner, P. M., \& Léa Rother, L. (2010). Bilan de l'Assistance Technique à la Fédération des Paysans du Fouta Djallon (FPFD) en Guinée: 15 ans d'accompagnement AFD. Retrieved from http://www.oecd.org/derec/france/48476118.pdf

Tinsley R. L. (2004). Developing Smallholder Agriculture: A global perspectives. Brussels, Belgium: AgBe Publication. http://dx.doi.org/10.1016/j.agsy.2008.08.003

USAID. (2006). Production et Commerce de la Pomme de terre en Guinée Etude de faisabilité. Retrieved from http://pdf.usaid.gov/pdf_docs/PNADJ163.pdf

World Bank. (2008). World Development Report 2008. Agriculture for Development. World Bank, Washington, DC.

\section{Copyrights}

Copyright for this article is retained by the author(s), with first publication rights granted to the journal.

This is an open-access article distributed under the terms and conditions of the Creative Commons Attribution license (http://creativecommons.org/licenses/by/3.0/). 